\title{
Denda Adat dalam Penjatuhan Pidana (Studi Kasus Kejahatan Kekerasan Di Pengadilan Negeri Merauke-Papua)
}

\author{
Aroma Elmina Martha
}

\begin{abstract}
Giving the criminal sanction, specially the gift of sanction with tradition fine in the cases of violence, like "Blood Fine" is valid to the citizens who have local law and the other ethnics who are loyal. "Blood Fine" can be a payment for fine, the assistance of financial on medical treatment and apologize. The judge in taking his decision must consider the local criminal law, more special the custom fine, but in the cases of violence on woman positive law ignore the local law.
\end{abstract}

\section{Pendahuluan}

Kejahatan kekerasan bukanlah hal baru untuk dibicarakan. Fakta di berbagai media massa menunjukkan betapa seringnya pemberitaan mengenai korban kekerasan. Pembunuhan, pemerkosaan, penganiayaan, pelecehan bahkan perilaku yang menunjukkan kekerasan dianggap menjadi sebagai hal biasa oleh masyarakat.

Perilaku kekerasan yang dilakukan ini semakin bervariatif nilainya karena menyangkut ukuran atau norma setempat. Begitu pula halnya di Indonesia yang terdiri atas beragamnya suku bangsa yang tersebar di berbagai wilayah. Peranan adat tidak dapat dipungkiri memberi pengaruh pada setiap perilaku masyarakat tertentu, seperti dalam

setiap perilaku individu hingga upacara yang berkaitan dengan kehidupan manusia, maupun pemberian sanksi bagi pelaku yang melanggar adat.

Pada aspek pemberian sanksi misalnya, tidak sedikit putusan pengadilan di tanah air kita yang memperhatikan adat istiadat/kebiasaan masyarakat setempat. $\mathrm{Hal}$ ini disebabkan beragamnya suku bangsa yang tersebar dari ujung timur Merauke Papua sampai ke ujung barat Sabang, Aceh, di Sumatera, maka sanksi pidana adat merekapun berbeda-beda.

Selama ini tulisan mengenai kejahatan kekerasan suku-suku di Papua khususnya Merauke sangat jarang dilakukan. ${ }^{1}$ Bahkan catatan tentang hukum pidana adat yang

${ }^{1}$ Catatan maupun dokumen dari 2 keuskupan di Merauke menunjukkan hal tersebut. Keuskupan di Merauke memegang peran yang cukup penting terutama yang berkaitan dengan dokumen maupun data adat 
berkaitan dengan sanksi terhadap pelaku belum didokumentasikan. Padahal ini penting mengingat ketentuan Undang-undang mengenai UU Nomor 21 Tahun 2001 tentang Otonomi Papua (UUOP) yang memungkinkan pemberlakuan sanksi pidana adat dan peradilan adat bagi pelaku. ${ }^{2}$

Papua $^{3}{ }^{3}$ adalah wilayah yang terdiri dari 27. suku bangsa. Misalnya suku Marind di Merauke Papua. Hingga kini eksistensi suku ini masih ada termasuk pola kehidupan perkawinan yang mereka jalani tergolong unik. Misalnya perkawinan adat (lanik anggai) di suku Marind. Dalam Suku Marind ini dikenal dengan tradisi otiv-bombari, yaitu suatu tradisi dimana pengantin wanita di malam pertama perkawinannya tidak langsung bersama suaminya, melainkan di-hak-i bersama oleh masyarakat. Maksudnya adalah berupa penikmatan seksual oleh tokoh adat atau orang tertentu yang memiliki kesaktian. ${ }^{4}$

Akibat dari perilaku ini ialah akan terdapat kemungkinan menjadi janin sebagai akibat tradisi otiv-bombari atau wad bakev yang secara biologis mengaburkan asal-usul anak yang kelak lahir, yang akhirnya akan menimbulkan akibat hukum di kemudian hari. Dari segi ini maka kedudukan wanita mènjadi sangat lemah, tidak ubahnya sebagai barang yang dapat dipindahtangankan. ${ }^{5}$ Bahkan, apabila ada seorang perempuan suku Marind yang tiba masa akan melahirkan, maka dia akan pergi ke hutan untuk "bersalin" di sana, tanpa dibantu siapapun. Setelah proses persalinan selesai barulah ia akan kembali ke rumah membawa bayi yang baru dilahirkan serta berkumpul kembali dengan keluarganya. ${ }^{6}$

Dalam kondisi demikian, tidak semua perilaku dianggap sebagai kekeraśan oleh adat setempat. Namun, bukan tidak berarti suku Marind tidak menjatuhkan sanksi pidana Adat kepada pelaku kekerasan. Masalahnya adalah, kriteria kekerasan itu sendiri sangatlah bergantung kepada persepsi pidana adat yang terdapat dalam suku Marind.

Namun, dalam kasus lain, apabila ada orang yang sedang mengendarai kendaraan, dan kendaraannya tersebut menabrak hewan

Marind Merauke. Khususnya suku Marind yang merupakan salah satu suku terbesar di Papua-Irian Jaya.

${ }^{2}$ Lihat Pasal 53 UU No. 26 Tahun 2001 tentang Otonomi Papua

'Dulu dikenal dengan kepulauan lrian Jaya, namun sekarang telah dirubah menjadi Papua, berdasarkan UU No. 21 Tahun 2001 mengenai Otonomi Khusus bagi Daerah Papua.

"Aroma Elmina Martha, "Identifikasi Kejahatan Kekerasan Terhadap Perempuan Di Suku Marind Merauke, Papua", Laporan Penelitian (Yogyakarta: FHUll, 2004).

${ }^{5} \mathrm{lbid}$. Informan dalam kasus ini adalah korban, yang memilh untuk melarikan diri karena tidak siap menerima kenyataan dia juga harus melayani adik ipar suaminya di malam pertama perkawinannya.

- $\mathrm{lbid}$. Sebagai illustrasi, di Nigeria salah satu nilai terpenting dalam kehidupan masyarakat Nigeria adalah keyakinan bahwa seorang wanita harus memberikan keturunan. Status sosial dari wanita tersebut bergantung dari berapa jumlah anak yang dilahirkan. Seorang istri yang tidak dapat hamil dalam masa 3 atau 4 tahun pertama perkawinan akan mulai berfikir untuk meninggalkan suaminya karenamenganggap suaminya mandul. Sebaliknya jika seorang wanita tetap tidak menghasilkan keturunan seumur hidupnya karena mandul, perut

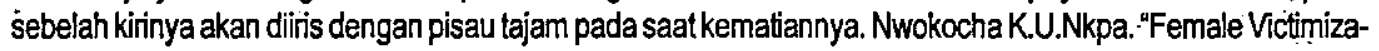
tion in Nigeria" dalam Hans Joachim Scheneider (ed.) The Victim in Intemational Perspective (Berlin: Walter de Gruyter, 1982), him. 234 
misainya seekor anjing atau babi hingga mati maka si pengendara ini akan dikenakan denda adat berupa pembayaran denda. Besarnya pembayaran denda ini akan bergantung kepada jenis kelamin hewan itu. Jika hewan ini berjenis kelamin jantan maka besarnya denda akan lebih sedikit daripada jika hewan itu berjenis kelamin betina. Alasannya adalah hewan betina dapat beranak-pinak sehingga perhitungan besarnya denda dihitung pada hewan yang ditabrak ditambah nilai. anak hewan itu jika hewan itu hidup dan ditambah nilai dari cucu hewan itu ditambah cicit dari hewan itu dan seterusnya. Sehingga patokan mengenai nilai besarnya denda adat yang harus dibayarkan oleh pelaku kepada pihak yang dirugikan juga akan bervariatif.?

Tulisan ini lebih lanjut hanya akan membatasi pada denda adat yang berhubungan dengan kasus-kasus kejahatan kekerasan yang diselesaikan di Pengadilan Negeri Merauke antara Januari hingga awal Juli (satu semester) tahun 2004. Lebih jauh akan mengkaji pada aspek pemberian sanksi pidana, khususnya pemberian sanksi berupa denda adat. Disamping itu juga akan dikaji mengenai apa saja bentuk-bentuk denda adat pada kasuskasus kejahatan kekerasan dan apakah hakim dalam menjatuhkan putusannya (pemidanaan) memperhatikan hukum pidana adat terutama denda adat.

\section{Hukum Pidana Adat dalam Penjatuhan Pidana}

Sampai saat ini ada pelbagai pendapat mengenai jumlah suku bangsa yang ada di Indonesia. Berdasarkan patokan jumlah bahasa (daerah) yang ada, maka Esser, Berg, atau St. Takdir Alisyahbana memperkirakan ada 200 sampai 250 suku bangsa di Indonesia. M.S.Jaspan telah menyusun suatu daftar sementara suku bangsa di Indonesia, yang mencapai jumlah $360 .^{8}$ Menurut Koentjaraningrat, di Sumatera ada 42 suku bangsa, di Jawa dan Madura 8 suku bangsa, di Bali dan Lombok 3 suku bangsa, di Kalimantan 25 suku bangsa, di Sulawesi 37 suku bangsa, di kepulauan Barat Daya 5 suku bangsa, di Maluku 9 suku bangsa, di Temate 15 suku bangsa, Timor 24 suku bangsa, di lrian Jaya 27 suku bangsa. ${ }^{9}$

Lebih jauh, van Vollenhoven secara sistematis telah membagi wilayah hukum adat Indonesia ke dalam 19 lingkungan hukum adat. Kesembilan belas lingkungan hukum adat tersebut adalah: Aceh, Gayo Alas dan Batak, Nias dan Batu, Minangkabau, Mentawai, Sumatera Selatan, Enggano, Daerah Melayu, Bangka dan Biliton, Kalimàntan, Minahasa, Sangi-Talaud, Gorontalo, Toraja, Sulawesi Selatán, Kepulauan Tenate, Ambon-Maluku, Kepulauan Barat daya, Irian, Timor dan - kepulauan sekitamya, Bali dan Lombok, Jawa

${ }^{7}$ Op.Cit,. Pengendara motor harus membayar denda adat tersebut sebesar Rp.3.000.000,- (tiga juta rupiah) karena responden menabrak seekor babi betina dan korban merasa puas serta tidak melanjutkan ke pengadilan. Responden lain pada lasus yang berbeda, pengendara mobil menabrak seekor anjing betina dan membayar denda adat sebesar Rp.500.000,- (lima ratus ribu rupiah) hlm. 53

- Soerjono Soekanto, Kedudukan Dan Peranan Hukum Adat di Indonesia (Jakarta: Kurnia Esa, 1981),

${ }^{9} / \mathrm{bid}$. Lihat juga Koentjaraningrat, Atlas Etnografi Indonesia, (Jakarta: Dian Rakya, 1969). 
Tengah dari Jawa Timur Surakarta dan Yógyäkarta: ${ }^{10}$ Dengan masuknya Papua (dulu Iriañ) kè dalam salah satu suku bangsa di Indonesia, dengan demikian diakui bahwa Papua memiliki hukum adat sendiri.Van Vollen Hoven menggunakan istilà "adatrecht" untuk penyébutan hukum adat. Lebih jauh jika digunakanan untuk bahan hukum, yang biasanya disêbut "Adat" orang ingin memberi nama tertentu, sehingga hảnyā menunjuk kepada "āàât yang mempunyai akibat-akibat hukum"." Di dälàm pidato pengukuhan sebagai guru besar yàng berjudul "Kesusilaan dan Hukum", Hàzäirin berpendapat bahwa:

"...adat itu adalah resapan...susilaan dälam masyārakat yaitu bahwa kaidahkaidah àdat itu merupakan kaidah-kaidah kesusilaan yang kebenarannya telah mendāpat pengakuan umum dalam masyarakat itu: ${ }^{n 12}$

Di daläm: pembahàasan lingkungan hukum adat, maka van Vollenhoven cenderung menggunakan sistematika sebagai berikut:

a. Tempat menemukan hukum adat

b. Ruaang lingkup lingkungan hukum adat yañg bersangkutan

c. Bentuk-bentuk masyarakat adat

d. Teñtäng pribadi

e. Pemerintahan, peradilan dan pengaturan

f. Hukum adát masyarakat:

- hukum adat kekeluargaan;
- hukum adat perkawinan; ' '

- . hukum adat waris

$\because$ - hukum adat

- hukum adat hutang- piutang

- hukum adat delik

- sistem sanksi

- perkembangan hukum adat ${ }^{13}$

Ter Haar di dalam Hilman Hadikusuma, mengunakan istilah "delik" atau "pelanggaran" untuk penyebutan sistem sanksi hukum adat masyarakat. Sebagaimana yang dikatakannya:

"Het woord delikt geeft dus aan een eenzijdige, door de weder partijniet vooraf uitdrukkeljk of stil zwijgend goedgevonden, handeling van evenwitchtsverstoring".

Jadj istilah delik itu menunjukkan adanya perbuatan sepihak yang dilakukan oleh pihak lain dengan tegas atau secara diam-diam dinyatakan sebagai perbuatan yang mengganggu keseimbangan. ${ }^{14}$ Dengan demikian dapaliah dikatakan bahwa hukum pidana adat adalah hukum yang menunjukkan peristiwa dan perbuatan yang harus diselesaikan (dihukum) dikarenakan peristiwa dan perbuatan itu telah mengganggu keseimbangan masyarakat.

Jika hukum pidana positip kita menitikberatkan pada adanya sebab ${ }^{15}$ sehingga seorang dapat diancam dengan hukuman, maka hukum pidana adat menitikberatkan pada adanya "akibat" sehingga seseorang dan kerabatnya

\section{${ }^{10}$ 'bid, him. 54}

11 van Vollenhoven, Orientasi dalam Hukum Adat Indonesia (Jakarta: Djambatan, 1981), hlm. 7

's Soérjoño, op.cit., him. 30

${ }^{13} \mathrm{lbid.,} \mathrm{hlm.} 55$

"Ter Haar Bzin, Mr B."Beginselen en stelsel van het adatrecht" dalam Hilman Hadikusuma, Hukum Pidanà Adat (Bandüng: Penerbit Alumni, 1984), him.18

${ }^{15}$ Bañdingkan dengan Moeljatino, Asas-asas Hukum Pidana (Bina Aksara: Jakarta, 1984). Ttentarig istilah peribuätän pidana yang menüujujuk kepada unsur kelakuan dạn akibat yang dilarang. 
harus bertanggungjawab pada akibat itu. ${ }^{16} \mathrm{Jadi}$ meskipun penyebab perbuatan pidana yang dilakukan tidak ada ketentuan atau larangannya, namun bila akibat tersebut membawa kerugian dan bertentangan dengan pihak yang terkena akibat, maka pihak yang menyebabkan akibat itu harus bertanggungjawab atas perbuatannya. Oleh karenanya menurut van Vollenhoven yang dimaksud dengan delik adat adalah perbuatan yang tidak boleh dilakukan, walaupun dalam kenyataannya peristiwa atau perbuatan itu hanya merupakan sumbang kecil saja. ${ }^{17}$

Soepomo, menurut uraian van Vollenhoven, sebagaimana yang dikemukakan oleh Hilman, membagi sistem hukum pidana adat ke dalam 9 kategori: ${ }^{18}$

1. Sistem terbuka

Apabila terjadi peristiwa atau perbuatan yang mengganggu keseimbangan maka petugas hukum (jika diminta) akan berusaha mengembalikan keseimbangan itu dengan mencari jalan penyelesaiannya, setelah kesepakatan dapat dicapai barulah dilihat pada norma-norma hukum adat yang ada atau menentukan hukum yang baru untuk memenuhi kesepakatan guna penyelesaian. Keputusan untuk penyelesaian ini seringkali bukan dari petugas hukum tetapi juga dari pihak yang merasa menugikan.

2. Perbuatan salah

Hukum pidana adat hanya mengenal delik yang bertentangan dengan kepentingan masyarakat setempat dan atau bertentangan dengan kepentingan pribadi seseorang.
Mengenai pembuktian, kadang tidak diperlukan pembuktian sama sekali dikarenakan umum sudah dianggap mengetahuinya atau dikarenakan umum sudah terkena akibat perbuatannya.

3. Pertanggungjawaban kesalahan

Pertanggungjawaban kesalahan yang dilakukan pelaku akan dinilai berdasarkan ukuran kedudukan pelaku itu di dalam masyarakat. Makin tinggi martabat seseorang di dalam masyarakat, maka semakin berat pula hukuman yang harus diterimannya, sebagai akibat kesalahan yang diperbuatnya.

4. Menghakimi sendiri

Selain hak menghakimi sendiri oleh penderita, apabila perbuatan salah itu mengenai kebendaan maka pihak yang terkena berhak menuntut nilai gantik kerugian berdasarkan ukuran nilai bendanya.

5. Membantu atau mencoba berbuat salah Hukum pidana adat tidak mengenal membantu atau mencoba berbuat salah. Oleh karenannya segala sesuatunya dianggap kesalahan yang harus diselesaikan apakah dengan hukuman atau ampunan.

6. Kesalahan residif

Kesalahan residif adat dapat berakibat dibuang untuk selama-lamanya dari lingkungan masyarakat.

7. Berat ringannya hukuman

Di dalam peradilan adat pelaksanaannya

${ }^{18}$ Hilman Hadikusuma, op.cit. hlm 18

$.17 \mathrm{lbid}$. hlm.19

ig /bid. hlm.32 
selalu didasarkan pada azas kekeluargaan, kedamaian dan kerukunan dan rasa keadilan. Hakim adat bebas menyelesaikan kasus pidana adat dengan memperhatikan suạsana dan kesadaran masyarakat setempat.

8. Hak mendapat perlindungan

Menurut hukum adat yang berlaku di beberapa daerah terdapat ketentuan bahwa seseorang yang bersalah dapat dilindungi dari ancaman hukuman dari suatu pihak apabila ia datang untuk meminta perlindungan kepada kepala . adat, penghulu agama atau raja.

9. Kesalahan di dalam hukum adat

Dalam hukum adat yang ditekankan adalah kesalahan itu telah terjadi. Tidak dipersoalkan apakah karena kesengajaan atau karena keàlpaan.

-Dengan demikian indikator di atas menunjukkan kriteria hukum pidana adat yang seçara umum dapat digunakan untuk menjelaskan perilaku yang dianggap masuk pada kriteria hukum pidana adat.

Setelah ada ketentuan Undang-undang Nomor 21 Tahun 2001 tentang Otonomi Khusus di Papua, maka kini diakui keberadaan peradilan adat di dalam masyarakat hukum adat tertentu (Pasal 50). Peradilan adat ini disusun menurut ketentuan hukum adat masyarakat hukum adat yang bersangkutan. Selanjutnya apabila dalam hal salah satu pihak yang bersengketa atau yang berperkara berkeberatan atas putusan yang telah diambil oleh pengadilan adat yang memeriksanya, pihak yang berkeberatan tersebut berhak meminta kepada pengadilan tingkat pertama di lingkungan badan peradilan yang berwenang untuk memeriksa dan mengadili ulang sengketa atau perkara yang bersangkutan (Pasal 51 Undang-undang Nomor 2.1 Tahun 2001).

Lebih jauh, akan dikemukakan mengenai teori kejahatan kekerasan. Kekerasan ini akan dibahas dalam perspektif teori sub budaya kekerasan. Teori Sub Budaya Kekerasan yang dikemukakan Wolfgang ini berdasarkan dua preposisi. $^{19}$

1. Norma-norma yang mengijinkan dan mendukung kekerasan sebelumnya telah terdapat dalam lingkungan pelanggar hukum sendiri.

2. Banyak pelanggar hukum - yang menghayati dan dipengaruhi oleh normanorma tersebut.

Asumsi yang dikemukakan Wofgang ini, juga berlaku pada perilaku kejahatan kekerasan terhadap perempuan. Umumnya bentuk kekerasan yang ditawarkan Wolfgang ini terjadi pada masyarakat (didasari pada struktur dan pola hubungan sosial ekonomi) yang menampilkan ciri dominasi dan ketidakadilan melalui proses yang komplek, sehingga menimbulkan sikap dan perilaku yang menduking pada kekenasan." Dengan

19 Lihat M.Wolfgang dan F. Ferracuti (The Subculture of violence. Towards in Integrated Theory in Crminology, 1967). Lihat juga Mulyana W. Kusumah, Analisa Kriminologitentang kejahatan kejahatan kekerasan. (Jakarta: Ghalia Indonesia, 1982), hlm. 42

20. Pada masyarakat Jawa misalnya, kekerasan terhadap perempuan hampir dapat dipastikan sebagian besar disebabkan dari adanya kecenderungan perilaku yang muncul dalam budaya masyarakat Jawa yang menganggap perempuan sebagai "konco wingking". Perempuan harus dalam posisi reaksi "nrimo".dalam bentuk sikap dan perilaku pasrah yang diterimanya sebagai bentuk pengabdiannya, termasuk sikap pasrah jika 
demikian tepatlah kiranya lebih jauh Wolfgang mengemukakan s...the greater the degree of integration of the individual into this subculture the higher the likehood that his behaviour will often be violent..."21

Demikian pula halnya apabila terjadi kejahatan kekerasan terhadap suku-suku asli di Papua, umumnya akan diselesaikan oleh peradilan adat masyarakat setempat. Namun tidak menutup kemungkinan untuk langsung menyerahkan masalah ini ke tingkat peradilan setempat. Seperti contohnya, putusan Nomor 58/Pid.8/2000/PN.Mrk, mengenai incest, yang dilakukan oleh seorang paman kepada keponakannya. Kasus perkosaan yang dilakukan terhadap -seorang bayi yang berumur 18 bulan ini tidak diserahkan ke pengadilan adat setempat, namun pihak yang berkeberatan (orang tua bayi tersebut) langsung mengajukan kepada pengadilan tingkat pertama. Terdakwa kemudian dijatuhi pidana selama 1 tahun 8 bulan penjara.

Mengenai penjatuhan putusan hakim yang berkaitan dengan penyimpangan adat setempat, maka tugas dan wewenang hakim ini pernah menjadi pembahasan panjang lebar yang bersifat polemik yang serius antara Ter Haar dan Hollemann. ${ }^{22}$ Menurut Holleman yang harus diperhatikan hakim adalah "kepandaian bertanya dan melihat secara pribumi." Hal yang terutama dikhawatirkan Holleman ialah bahwa hakim akan dijauhkan dari keharusan berusäha terus mènerus untuk memahami wujud pergaulan hidup itu sendiri dari orang-orang yang berada di bawah peradilannya. Sedangkan menurut Ter Haar, berkaitan dengan peran hakim dalam putusan adat, tidaklah semata berdasarkan pengamatan pribumi, hendaklah bukan hanya dari kenyataankenyataan materil, tetapi terlebih-lebih juga struktur rohaniahnya, jadi tidak hanya mempersaksikan sebagai orang lúar, tetapi sejauh mungkin untuk menghayati. Menghayati dan memahami adalah syarat mutlak (Conditio Sine Quanon), untuk peradilan hukum adat Lebih lanjut Ter Haar, putusan pengadilan hendaknya langsung tergantung dani ikatan-ikatan strukturil dan nilai-nilai dalam kesatuan sosial, bersistem di dalam batin dari keseluruhan hukum adat yang dihàsilkan oleh kenyataan hukum yang sesungguhnya. ${ }^{23}$

Berkaitan dengan uraian tersebut di atas, patut dikemukakan contoh putusan yang di dalamnya terdapat hathal menarik menyangkut suku bangsa dari subjek-subjek hukum yang terlibat dalam perkara kejahatan kekerasan tersebut. Putusan Nomor 29/Pid.B/2004/PN.Mrk. Terdakwa didakwa melanggar Pasal 351 ayat (1) Kitab Undang-undang Hukum Pidana mengenai penganiayaan. Di dalam putusan Majelis Hakim terdakwa dinyatakan terbukti bersalah melanggar pasal yang didakwakan yakni Pasal 351 ayat (1) KUHP. Terdakwa berasal dari suku Kei sedangkan sang korban

\footnotetext{
terjadi kekerasan terhadapnya. Lihat Aroma Elmina Martha, Perempuan, Kekerasan dan Hukum (Yogyạarta: UIl Press, 2002), him. 48

${ }^{21}$ Sue Titus Reid, Crime and Criminology (United States: CBS, College Publishing, 1995), hlm. 238

22 J.H.A. Logemann, "Tugas Hakim", dalam Terhaar; Hukum adat dalam Polemik IImiah (Jakarta:Bhrata; 1973), him. 65

23 lbid.
} 
berasal dari suku Marind. Pada kasus ini meșkipun terdakwa bukan berasal dari suku Marind namun tunduk pada hukum adat Maring, dan oleh karena itu terdakwa berușaha memulihkan keseimbangan yang terganggu akibat perbuatannya melakukan penganjiayaan itu dengan jalan membayar "denda dạrah" dan meminta mạaf. Terdapat hal yang menarik pada kasus ini ialah bahwa di samping terdakwa yang meminta keringanan hukuman juga si korban memintakan keringananan hükuman bagi diri și terdakwa, dengan alasan bahwa diantara terdakwa dengan korban maupun keluarga korban sudah terjadi perdamaian yang diujudkan dengan pembayaran "denda darah." Perilaku korban maupun keluarga korban ini selaras dengan indikator tentang hukum pidana adat yang telah dikemukakan di atas bahwa penyelesaian pidana ini didasarkan pada asas kekeluargaan, kedamaian dan kerukunan dan rasa keadillan. Oleh karena itu terdakwa kemudian dijatuhi pidana penjara 4 (empat) bulan dan 5 (lima) hari.

Hal ini beibeda dengan putusan Nomor 111/ Pid.B/2004/PN.Mrk mengenai penganiayaan dengan pasal serupa Pasal 351 ayat (1) KUHP yang dilakukan oleh terdakwa dari suku Bugis (Maros) terthadap korban dari suku Jawa. Di pengadilan tingkat pertama terdakwa dijatuhi pidana 1 tahun dan 3 bulan, sedangkan di tingkat banding dijatuhi pidana 1 tahun. Baik terdakwa maupun korban tidak tunduk pada hukum adat setempat. Hal yang menarik adalah pada kasus ini Penuntut Úmum yang memintakan keringanan hukuman bagi diri terdakwa, dengan alasan telah terjadi perdamaian diantara terdakwa dan korban, dan ternyata kemudian Majelis Hakim tingkat banding sependapat dengan pendapat Penuntut
Umum tersebut. Ini dapat ditafsirkan bahwa meskipun tidak ada denda darah yang dibayarkan namun yang penting sudah terjadi perdamaian diantara terdakwa dan korban, sehingga pemulihan keseimbangan yang terganggu di masyarakat itu dapat diwujudkan, dan digantikan dengan sanksi pidana. Dengan demikian, permintaan maaf memiliki nilai yang mendalam dalam rangka pemulihan keseimbangan yang terganggu di masyarakat.

Berkaitan dengan kejahatan kekerasan terhadap perempuan akan dikaji putusan Nomor 39/Pid.B/2004/PN.Mirk mengenai perkosaan Pasal 285 Kitab Undang-undang Hukum Pidana, yang dilakukan oleh terdakwa dari suku Asmat terhadap korban anaknya sendiri. Dalam kasus ini terdakwa mendalilkan bahwa menurut hukum adat Asmat diperbolehkan menghamili anak kandung sendiri asalkan si korban bukan berasal dari bibitnya (istrinya telah selingkuh dengan lakilaki lain ketika menikah dengan terdakwa). Bahkan di dalam upacara-upacara tertentu terjadi pesta seks sehingga terjadi perilaku seks di dalam keluarga sedarah,sekandung, yang dalam hal ini malah dapat dianggap sebagai hal yang "sakral." Dalil si terdakwa ini secara tidak langsung sudah mendasarkan diri padar teori Sub Budaya Kekerasan, bahwa perilakunya melakukan perkosaan itu kepada anaknya sendiri diijinkan dan didukung oleh norma-norma yang terdapat di dalam lingkungan si terdakwa dan si korban, yaitu sub budaya kekerasan yang ada pada suku Asmat. Terdakwa dituntut dengan pidana penjara 9 tahun dan temyata Majelis Hakim sependapat dengan tuntutan itu sehingga terdakwa dijatuhi pidana 9 tahun. Dalamkasus ini, dapat ditafsirkan bahwa Majelis Hakim dalam putusannya berpendirian hukum 
positip lebih dikedepankan daripada hukum pidana adat setempat. Dengan demikian pada kasus ini hakim mengabaikan hukum pidana adat suku Asmat. Alasannya perkosaan terhadap anak kandung (incest) bertentangan dengan aturan KUHP yang jelas-jelas melarang perbuatan pidana perkosaan. ${ }^{24}$

\section{Denda Adat pada Kasus Kejahatan Kekerasan di Merauke}

Di muka sudah dikemukakan beberapa putusan tentang kejahatan kekerasan $\mathrm{di}$ Merauke yang di dalamnya terdapat beberapa variasi pemidanaan, terutama adanya pembedaan berat atau ringannya penjatuhan pidana, dan penjatuhan pidana ini erat kaitannya dengan adanya denda adat yang telah dibayarkan dalam kasus-kasus itu. Denda adat merupakan tindakan-tindakan yang menjadi koreksi atau reaksi terhadap setiap perbuatan yang menimbulkan akibat yang dirasa merugikan. Tujuan dari reaksi atau koreksi ini adalah pemulihan keseimbangan di masyarakat. ${ }^{25}$ Oleh karena itu, akan dikaji lebih lanjut putusan itu terutama yang berkaitan dengan denda adat. Putusan Nomor 29/Pid.B/ 2004/PN.Mrk. Terdakwa dari suku Kei dinyatakan terbukti bersalah melanggar Pasal 351 ayat (1) Kitab Undang-undang Hukum Pidana mengenai penganiayaan, adapun sang korban berasal dari suku Marind. Pada kasus ini terdakwa diharuskan membayar denda adat berupa "denda darah" dan meminta maaf. "Denda darah" tersebut biasanya dapat dilakukan dengan jalan mengorbankan babi atau keharusan bagi terdakwa maupun keluarga terdakwa untuk dianiaya dengan kualitas yang sepadan. Namun, dalam kasus ini terdakwa diharuskan membayar "denda darah" yang diujudkan dengan membayar sejumlah uang sebesar Rp.6.000.000,- (enam juta rupiah) untuk membayar biaya pengobatan korban di rumah sakit. Oleh karena itu terdakwa kemudian dijatuhi pidana penjara 4 (empat) bulan dan 5 (lima) hari. Berbeda halnya dengan putusan Nomor 111/Pid.B/2004/PN.Mrk tentang penganiayaan dengan Pasal 351 ayat (1) KUHP yang dilakukan oleh terdakwa dari suku Bugis (Maros) terhadap korban dari suku Jawa. Dalam kasus ini tidak terdapat denda' adat yang harus dibayarkan oleh pelaku kepada si korban, sehingga di pengadilan tingkat pertama terdakwa dijatuhi pidana 1 tahun dan 3 bulan, sedangkan di tingkat banding dijatuhi pidana 1 tahun. Dengan demikian, putusan pidana (pemidanaan) yang dijatuhkan memiliki perbedaan yang cukup besar bila dibandingkan dengan perkara serupa yang di dalamnya terdapat denda darah yang dibayarkan.

Namun lain lagi dengan putusan Nomor 39/Pid.B/2004/PN.Mrk mengenai perkosaan yang dilakukan oleh terdakwa dari suku Asmat terhadap korban anaknya sendiri. Terdakwa

${ }^{24}$ Aroma Elmina Martha, 1oc.cit.

${ }^{25}$ Iman Sudiyat, Hukum Adat Sketsa Asas (Yogyakarta:UGM, 1981), hlm. 180. Tindakan-tindakan reaksi atau koreksi adat itu misalnya a. Pengganti kerugian non materiil b. Pembayaran uang adat c. Selamatan untuk membersihkan masyarakăt dari segala kotoran gaib d. Penutup malu; minta maafe. Berbagai rupa pidana badan hingga sampai kepada pidana mati f. Pengasingan dari masyarakat serta meletakkan orang di luar tata hukum. 
mendalilkan bahwa menurut hukum adat Asmat diperbolehkan menghamili anak kandung sendiri alasannya si korban bukan berasal dari bibitnya (istrinya selingkuh dengan laki-laki lain sehingga melahirkan si korban itu). Dalam kasus ini tidak ada denda darah yang harus dibayarkan oleh terdakwa kepada korban dan si' korban memaafkan perilaku kejahatan kekerasan yạng dilakukan oleh terdakwa tersebut, sehingga terdakwa dijatuhi pidana 9 tahun. Dengan demikian, meskipun sudah ada pemberian maaf dari si korban namun hal itu tidak memberikan alasan yang cukup signifikan bagi hakim untuk mengurangi pidana yang dijatuhkan.

\section{Simpulan}

Pada aspek pemberian sanksi pidana khususnya pemberian sanksi berupa denda adat yang terdapat dalam kasus-kasus kejahatan kekerasan berupa "denda darah" tidak hanya berlaku bagi warga yang memiliki hukum adat tersebut namun juga berlaku bagi warga suku lain yang menundukkan diri kepada hukum adat setempat. "Denda Darah" ini tidak berlaku dalam hal pihak-pihak yang terlibat dalam delik tersebut bukanlah berasal dari suku yang memiliki budaya setempat. Selain itu juga, "denda darah" pada saat ini dapat diujudkan dalam bentuk bantuan biaya pengobatan, pembayaran denda. Denda adat yang berupa permintaan maaf dari pihak yang bersalah (terdakwa) kepada pihak yang menderita (korban) memiliki nilai yang juga cukup berarti.

- Dalam penjatuhan pidana, hukum pidana adat-yang dalam hal ini berupa denda adat memiliki peran yang cukup besar dalam penjatuhan berat ringannya pidana. Dengan kata lain hakim dạlam menjātúhkan' putusannya (pemidanaan) memperhatikan hukum pidana adat terutama denda adat. Namun demikian, dalam kasus-kasus tentang kejahatan kekerasan terhadap perempuan hukum pidana positip lebih dikedepankan atau malahan dapat dikatakan hukum pidana positip pada kasus kejahatan kekerasan terhadap perempuan mengabaikan hukum adat setempat.

\section{Daftara Pustaka}

Friedmann, Lisa, "Wife Assaúlt" dalam Connie Guberman et al.(editors). No Safe Place. Violence Against Women and Children, Toronto. Ontario: Women Press, 1985.

Harkrisnowo, Harkristuti, Wajah tindak kekerasan tehadap perempuan di indonesia, makalah di sampaikan pada semiloka nasional mengenai kemitraan pemerintah dan LSM dalam. pencegahan dan penanggulangan tindak kekerasan terhadap perempuan, yang diselenggarakan Menperta; beberapa LSM dan Organisasi Internasional di Jakarta, 26-27 Januari 1999.

Koentjaraningrat, Atlas Etnografi Indoniesia, Jakarta: Dian Rakyat, 1969.

Kusumah, Mulyana W., Analisa Kriminologi tentang kejahatan-kejahatan kekerasan, Jakarta: Ghalia Indonesia, 1982.

Logemann, J.H.A.. Tugas Hakim dalam Terhaar, Hukum adat dalam Polemik IImiah, Jakarta: Bhrata, 1973. 
Martha, Aroma Elmina, "Identifikasi Kejahatan Kekerasan Terhadap Perempuan Di Suku Marind Merauke, Papua", Laporan. penelitian (Yogyakarta: Lembaga Penelitian UII, 2004.

-- - - - - - Perempuan, - Kekerasan dan Hukum, Yogyakarta: UII Press, 2002.

Moeljatno, Asas-asas Hukum Pidana, Jakarta: Bina Aksara, 1984.

Nkpa, Nwokocha K.U. "Female Victimization in Nigeria" dalam Hans Joachim Scheneider (ed.) (1982). The Victim in International Perspective. Walter de Gruyter: Berlin.

Vollenhoven, Van., Orientasi dalam hukum adat Indonesia, Jakarta: Djambatan, 1981.
Reid, Sue Titus, Crime and Criminology. CBS, College Publishing: United States, 1995.

Soekanto, Soerjono, Kedudukan dan peranan' hukum adat di Indonesia, Jakarta: Kurmia Esa, 1981.

Soemarman, Anto, Hukum Adat: Perspektif Sekarang Dan Mendatang, Yogyakarta: Adicita Karya, 2003.

Sudiyat, Iman, Hukum Adat Sketsa Asas, Yogyakarta: UGM, 1981.

Ter Haar Bzn, Mr B. "Beginselen en stelsel van het adatrecht" dalam Hilman Hadikusuma, Hukum Pidana Adat, Bandung: Penerbit Alumni, 1984.

Undang-Undang Nomor 26 tahun 2001 tentang Otonomi Khusus Papua. 